\title{
Intensification of the Enzymatic Esterification Process by Ultrasounds
}

\begin{abstract}
ANAMARIA VARTOLOMEI, IOAN CALINESCU, MIRCEA VINATORU, ADINA IONUTA GAVRILA*
University Politehnica of Bucharest, Faculty of Applied Chemistry and Materials Science, Bioresources and Polymer Science Department, 1-7 Gh. Polizu Str., 011061, Bucharest, Romania

Ultrasound application is a method of enhancing the performance of biocatalysts. Enzymes performance is strongly influenced by the nature of the reaction medium. Ultrasounds have the potential to significantly influence the activity of the enzymatic processes, provided that the energy input is not too high to inactivate the enzyme. In the present paper a systematic study on ultrasound-assisted enzymatic esterification for aroma esters preparation is described. Thus, by ultrasound assisted enzymatic esterification $i$-amyl acetate was obtained. The method is efficient, mild, and environmentally benign. Significant improvements were obtained in comparison to conventional method. The results show a favourable perspective of the ultrasound technique to improve the process efficiency and reduce the reaction time. The commercial aroma esters synthesis will be potentially realized due to this ultrasound-promoted esters synthesis method.
\end{abstract}

\section{Keywords: ultrasounds, enzyme, esterification, i-amyl acetate}

Organic esters are important compounds with special properties used as solvents, perfumes, and flavours. Specialty esters are synthesized by esterification of the short chain carboxylic acids (such as acetic, propionoic, and butyric acids) with alcohols (such as ethanol, butanol, $i$-amylic alcohol, geraniol, menthol, citronelol, etc) and they are widely used as flavors and fragrances in the food, pharmaceutical and cosmetic products [1]. Flavours are used in soaps, deodorants, shampoos, creams, and shower gels, and fragrances are used in lipsticks, toothpaste, lip gloss and lip balms [2]. Among these specialty esters, $i$ amyl esters (especially $i$-amyl acetate) are of commercial importance due to the strong banana flavour. They can be used in a variety of foods, such as honey, artificial coffee and beverages (especially fermented alcoholic beverages, such as beer, sake, and wines) [3].

Flavour esters can be extracted directly from natural sources, but this method is relatively expensive by comparison with classical chemical esterification that is cheaper and faster. The classical method for the synthesis of $i$-amyl acetate is the Fischer esterification reaction. The reaction is carried out at high temperature using concentrated acids as catalyst. This ester can be prepared by the reaction of a carboxylic acid with $i$-amyl alcohol in the presence of a catalyst such as concentrated sulfuric acid, hydrochloric acid, p-toluene sulfonic acid, or the acid ion exchange resin. The equilibrium of this Fischer esterification is reached after a few hours of refluxing. The position of the equilibrium can be shifted by adding more acid or alcohol, depending on cost or availability [4].

These conventional chemical methods present some disadvantages like low purity of products, using acids as catalysts, necessity of high temperatures leading to unsafe and sometimes inefficient methods, unwanted in food and cosmetics preparations. The biotechnological methods using enzymes as catalysts offer an opportunity to perform enzymatic esterification under milder conditions with a better quality of the esters [5-9].

Enzymatic esterifications for aroma and perfumes synthesis are carried outusing lipases as biocatalysts. Thus, various lipases are used for preparation these specialty esters such as Rhizopus oryzae, C. antarctica, $T$. lanuginosus, $P$. fluorescens, $R$. japonicus, Candida rugosa, and Staphylococcus simulans [2]. i-Amyl acetate (banana aroma) was prepared using Rhizopus miehei as the esterification biocatalyst, and conversions were higher than $95 \%$ (reaction time: 72 hours, reaction temperature: $40^{\circ} \mathrm{C}$ in the presence of $n$-heptane as solvent) $[10,11]$. Another aroma ester $n$-amyl butyrate was synthetized using immobilized Candida rugosa lipase and the yield was over $90 \%$ with (reaction time $48 \mathrm{~h}$ and $n$-hexane solvent) $[3,12]$.

Ultrasounds (US) with frequencies ranging from $20 \mathrm{kHz}$ up to $5 \mathrm{MHz}$ are a type of mechanical energy which do not exhibit ionizing radiation properties. The propagation of ultrasound in the fluids generates waves and produces successive compression and rarefaction cycles. When the ultrasonic power exceeds a certain value in the rarefaction phase the molecules of fluids are pulled apart and as consequence cavitation bubbles are formed. Bubbles thus generated are not stable and suffer a sudden collapse releasing tremendous amount of energy in a very localized space volume when the amplitude of acoustic pressure exceeds a thresholds e.g. 0.06-0.1 MPa for distilled water $[13,14]$. During cavitation bubbles collapse, the temperature and pressure inside the bubbles reach more than $5000 \mathrm{~K}$ and $1000 \mathrm{~atm}[14,15]$. In the presence of the small solid surfaces (heterogeneous reactions), the collapse of bubbles near the solid surface leads to formation of microjets which improve the mass transfer and speed up the transport processes [16]. At low acoustic pressure, microbubbles of various sizes present in a liquid could be forced to oscillate in response to alternating pressure waves of ultrasound, without cavitation. Such oscillations generate shear forces and enhance fluid flow and mass transfer that could be used in various chemical processes $[17,18]$.

The ultrasounds frequency and power have an influence on the cavitation bubbles collapse and consequently affect the enzyme activity by three main mechanisms. First effect is pure thermal, due to the rising of the temperature during cavitation. Free radicals generated by water or other polar liquids sonolysis represent the second effect, and the third effect is produced by mechanical shear forces formed by microstreaming and shock [19]. Therefore, ultrasounds can influence the activity of enzymes in the esterification processes if the input energy is not too high to produce the deactivation of enzyme, mostly via the third effect. Applying a high ultrasonic power can lead to cell destruction being considered as microbicide, while low power increases the

\footnotetext{
*email: email: adinagav@yahoo.com
} 
growing of microbial cell cultures [20]. Nevertheless, the presence of ultrasound influences the enzyme activity and stability and depends on the sonication parameters such as the applied ultrasound power and frequency. Numerous scientists have observed that enzymatic reactions performed under mild ultrasound conditions leads to an increased enzyme activity [21].

The aim of this paper is to explore the intensification of enzymatic esterification by applying of ultrasounds in order to synthesize $i$-amyl acetate used as aromas and flavours in the food and cosmetic industry. The esterification was carried out in solvent free system, using lipase Lypozyme 435 from Candida antarctica as biocatalyst for ultrasoundassisted process.

\section{Experimental part \\ Materials}

Lipase Lipozyme 435 from Candida antarctica, supported on a macroporous acrylic resin was kindly provided by Novozymes A/S (Denmark). All chemicals: i-amyl alcohol (Merck), acetic acid (Merck), i-amyl acetate - standard for GC analysis (Aldrich) were analytical grade.

\section{Esterification of acetic acid with i-amyl alcohol \\ Classical esterification}

Acetic acid $(50 \mathrm{mmol}), i$-amyl alcohol $(100 \mathrm{mmol})$ and corresponding amount of enzyme -Lipozyme 435 were mixed and heated to the reaction temperature. The progress of the reaction was monitored by collecting small amount of samples ( $0.02 \mathrm{~g}$ sample) at different time intervals, and the ester concentration was analysed by gaschromatographic analysis (GC analysis). The reaction was carried out in a $200 \mathrm{~mL}$ reactor (round bottom cylindrical vial) equipped with mechanical agitation and reflux condenser. The temperature of the reaction mixture was measured using an optical fibre thermometer. The considered parameters were: enzyme concentration, temperature and reagents molar ratio. In order to establish the best esterification conditions, the experiments were carried out by changing one parameter and maintain all the others constant.

\section{Ultrasonic esterification}

Experiments in the presence of ultrasounds were performed using an ultrasonic bath (Ultrasonic cleaning bath COLIBRI L488, volume $200 \mathrm{~mL}$, $22 \mathrm{~W}$, frequency 66 $80 \mathrm{kHz}$, STIMIN SRL, Italy) being equipped with an additional heating system, an ultrasound power variation system and a mechanical stirrer.

\section{GC Analysis}

Quantitative analysis of the esters was performed using an HP 6890 gas chromatograph equipped with flame ionization detector (FID). The oven is set to heat the column from 50 to $250^{\circ} \mathrm{C}$ with a gradient of $10^{\circ} \mathrm{C} / \mathrm{min}$. Helium is used as column carrier gas (flow rate $1 \mathrm{~mL} / \mathrm{min}$ ). $n$-Butanol is used as the internal standard for determining ester concentrations. The volume of the injected mixture was 1 ìL. Individual standards of $i$-amyl alcohol and $i$-amyl acetate were analysed and their retention time was recorded and the ester samples were compared under similar conditions. The ester concentration was determined using a calibration curve of pure $i$-amyl acetate with concentration ranging from 5 to $60 \mathrm{mg}$ ester $/ \mathrm{g}$. Samples were diluted 1:10 with a standard solution of $5 \% n$-butanol in methanol before analysis. The samples were analysed in duplicates.

\section{Results and disscutions}

\section{a)Influence of enzyme loading}

The ester concentration depends on the enzyme loading. It is important to identify the minimum amount of catalyst (enzyme) that maximizes the amount of ester synthesized over a fixed period of time, due to the high cost of enzymes that may raise economical aspects questions. The reaction temperature was kept constant at $50^{\circ} \mathrm{C}$ and the molar ratio alcohol: acid of 2:1. Increasing the amount of biocatalyst from $0.8 \%(8.5 \mathrm{mg} / \mathrm{g})$ to $6.5 \%$ (70 mg/g), the amount of ester obtained increased from 60.95 to $428.3 \mathrm{mg}_{\text {ester }} / \mathrm{g}$. The influence of enzyme loading on the ester concentration is presented in figure 1.

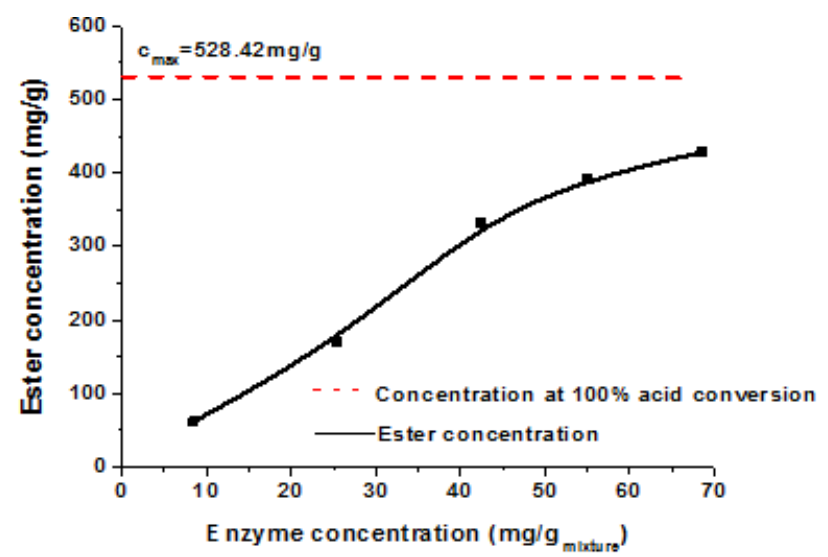

Fig. 1. Influence of enzyme concentration on $i$-amyl acetate ester concentration (reaction conditions: temperature $50^{\circ} \mathrm{C}$ and the molar ratio alcohol: acid of 2:1)

Increasing the amount of enzyme led to an increase in the amount of $i$-amyl acetate obtained. However, increasing the amount of catalyst from 50 to $70 \mathrm{mg} / \mathrm{g} \mathrm{(40 \%}$ increase) do not have a significant effect on total acid conversion, the ester concentration increasing only by $12.5 \%$. This suggests that the use of more enzyme is not very effective considering the costs of the enzyme. For this reason all subsequent experiments were performed using $50 \mathrm{mg}$ of enzyme/g reaction mixture.

b) Influence of the molar ratio

The molar ratio of reactants is usually one of the most important parameters in enzymatic esterification reactions. Because the reaction is reversible, an increase in the concentration of one of the reagents (in particular, $i$ amyl alcohol) can shift the chemical equilibrium towards the products, leading to higher conversions. In addition, high concentrations of acetic acid may reduce the reaction rate due to the acidification of enzyme in the acidic media and its deactivation. To find an optimal ratio of alcohol to acid, to reduce the enzyme deactivation by high acidic media, several ratios ranging from 1:1 up to $3: 1$ were investigated. The constant reaction conditions were the reaction temperature of $50^{\circ} \mathrm{C}$ and the enzyme concentration of $50 \mathrm{mg} / \mathrm{g}$ reaction mixture, and the results are represented in figure 2.

As show $n$ in figure 2 the use of alcohol excess has led to an increase in acid conversion. Increasing the molar ratio alcohol: acid from 1:1 to 2:1 resulted in a significant increase in the concentration of $i$-amyl acetate. However, too much alcohol (a molar ratio of 3:1) leads to a smaller increase in conversion. Moreover, alcohol has also hydrophilic interactions with the water layer at the surface of the enzyme. This leads to the modification of the protein structure of the enzyme causing inhibition and the decrease of enzyme activity [22]. For this reason all 


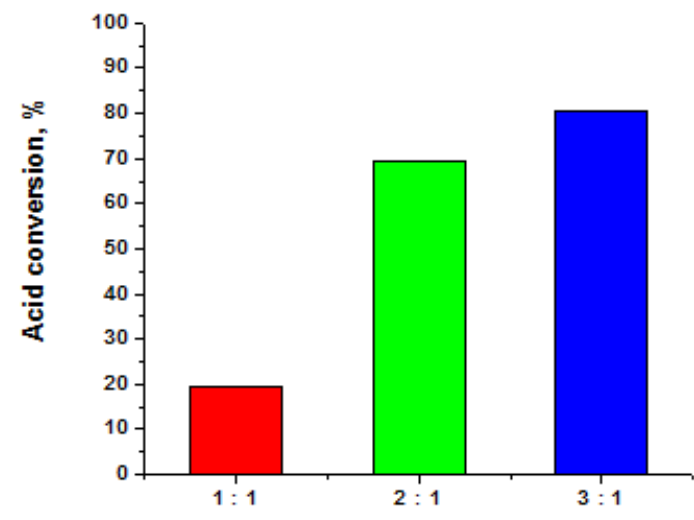

Molar ratio $i$-amyl alcohol : acetic acid

Fig. 2. Influence of the molar ratio on the acid conversion in the esterification process (reaction conditions: temperature $50^{\circ} \mathrm{C}$ and enzyme loading $50 \mathrm{mg} / \mathrm{g}$ )

subsequent experiments were performed using molar ration alcohol to acid of 2:1.

\section{c) Influence of temperature}

The reaction temperature is an important factor for enzymatic catalysed reactions because lipase activity is temperature dependent. The following experiments were performed in the presence of the Lipozyme 435 as biocatalyst, at different temperatures ranging as 40,50 , 60 , and $70^{\circ} \mathrm{C}$, molar ratio $i$-amyl alcohol:acetic acid of $2: 1$ with slight mechanical agitation. The influence of temperature on the concentration of the ester concentration in the enzymatic esterification process is shown in figure 3.

As shown in figure 3 an increase of temperature led to an increase in i-amyl acetate concentration. At a higher temperature than $60^{\circ} \mathrm{C}$, the denaturation phenomenon of the enzyme may occur, which would lead to an increase in the reaction time and, respectively, a decrease in ester yield. Based on these results the subsequent experiments were performed at $50^{\circ} \mathrm{C}$ to avoid the enzyme denaturation.

d) Intensification of the enzymatic esterification process by ultrasound. The influence of ultrasonic power

The study of the influence of ultrasounds on the esterification process was carried out by performing experiments at different ultrasonic power setup. The ultrasonic bath was not equipped with a power control system and we adjusted the power using an autotransformer with variable the voltage. We used 100, 150 and $200 \mathrm{~V}$, and we determined the ultrasonic power by a calorimetric method [23]. The values determined for the ultrasonic power at different voltages were 3, 6 and 8.5 $\mathrm{mW} / \mathrm{cm}^{3}$. The testing of ultrasonic power influence on ester yield was carried out at different temperatures of $40^{\circ} \mathrm{C}, 50$

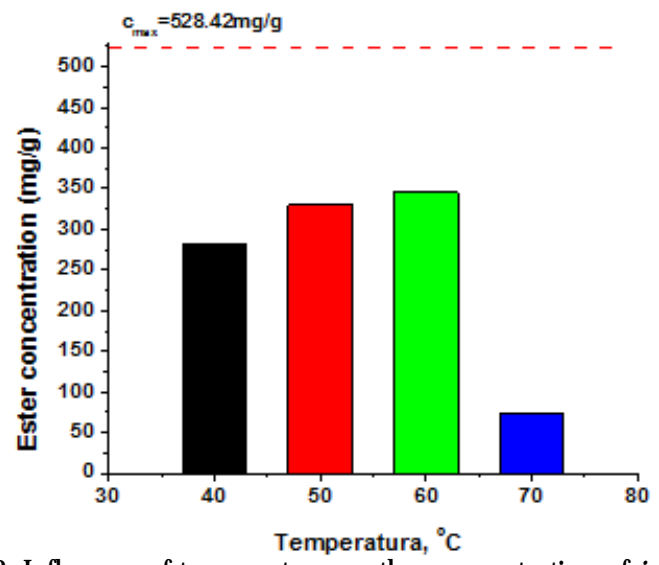

Fig. 3. Influence of temperature on the concentration of $i$-amyl acetate in the enzymatic esterification process (reaction conditions: enzyme loading $50 \mathrm{mg} / \mathrm{g}$ and the molar ratio alcohol: acid of $2: 1$ )

and $60^{\circ} \mathrm{C}$, respectively. The other parameters were kept constant, a molar ratio of $i$-amyl alcohol: acetic acid of 2:1, Lipozyme 435 amount $50 \mathrm{mg} / \mathrm{g}$ and mechanical agitation. The variation of the ester concentration in the ultrasound assisted enzymatic esterification process for different temperatures are shown in figure 4.

Ultrasonic power is a significant parameter in assisted ultrasound processes. This together with the frequency can have both positive and negative effects on the rate of esterification and the catalytic activity of lipase. The ultrasonic power affects the biocatalyst structure and its molecular conformation. For this reason, a low power ultrasonic bath was used and we tried to find the optimum acoustic power for the esterification of acetic acid with $i$ amyl alcohol. Thus, the experiments were performed at different ultrasonic powers from 3 to $8.5 \mathrm{~mW} / \mathrm{cm}^{3}$ in order to identify its influence on the enzymatic process, correlated with reaction temperature. As shown in figure 4 , a different behaviour of the ultrasonic assisted esterification reactions at the three temperatures can be observed. Temperature has a negative impact on the cavitation phenomenon, the higher the temperature the lower energy of collapsing bubbles [13] and for this reason it is important to find such temperature to cope with enzyme performance and US efficiency to achieve the maximum concentration of $i$-amyl acetate. Thus, at temperatures of 40 and $50^{\circ} \mathrm{C}$, the ester concentration increased with the increase of the ultrasonic power, a higher conversion was obtained for $50^{\circ} \mathrm{C}$ when a maximum ester concentration $(386 \mathrm{mg} / \mathrm{g}$ ) was reached. On the other hand, the experiments at $60^{\circ} \mathrm{C}$ showed that increasing the ultrasonic power has a detrimental effect on ester yield. This may be a consequence of combined effect of ultrasound and temperature on enzyme (denaturation of it). This result is due to the fact that, with increasing
A) $40^{\circ} \mathrm{C}$

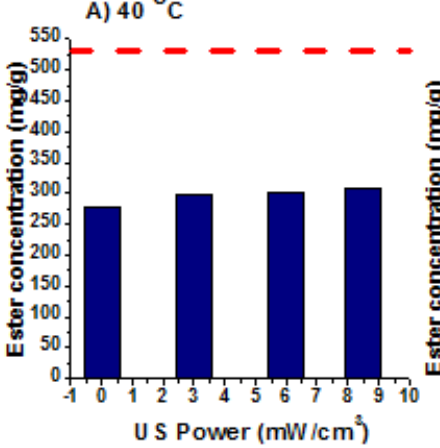

B) $50^{\circ} \mathrm{C}$

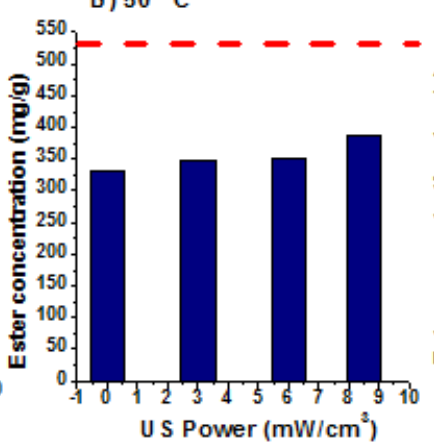

C) $60^{\circ} \mathrm{C}$

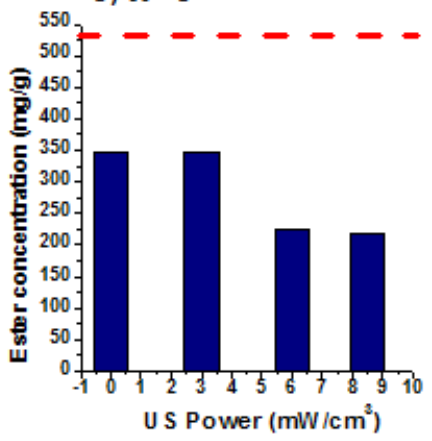

Fig. 4. Influence of ultrasonic power on the concentration of $i$-amyl acetate in the enzymatic esterification process for different temperatures (A) $\left.40^{\circ} \mathrm{C}, \mathrm{B}\right) 50^{\circ} \mathrm{C}$ and

C) $60^{\circ} \mathrm{C}$ ) (reaction conditions: enzyme loading $50 \mathrm{mg} / \mathrm{g}$ and the molar ratio alcohol: acid of 2:1).

- - Ester concentration for $100 \%$ acid conversion $c_{\operatorname{mex}}=528.42 \mathrm{mg} / \mathrm{g}$ 
temperature, the biocatalyst is sensitive to higher ultrasound powers because under harsh conditions, intramolecular hydrogen bonds break down inside the enzyme leading to the modification of the conformational structure, and subsequently to deactivation or reduction of catalytic activity of lipase [22]. In addition, at high temperatures, the vapours entering inside the cavitation bubbles cushion the cavitation effect acting as shock absorbers [13].

We cannot rule out the possible influences of US via capillarity effect, ultrasonic electrical charges developing on a capillary tube filled with electrolytes (U-effect I and U-effect II), acetic acid playing the electrolyte role [2425]. Enhancing the mass transfer as well as enlarging and shrinking the enzyme's support pores should also considered, but at this stage of experimental work is not possible to quantify this effect.

\section{Conclusions}

Ultrasound assisted enzymatic synthesis of i-amyl acetate was performed using Lipozyme 435 in solventfree system. In order to find the highestester concentrations the effect of different parameters (enzyme loading, alcohol to acid molar ratio, ultrasonic power and temperature) on the synthesis of $i$-amyl acetate by enzymatic catalysis was studied. The best result were obtained using $50 \mathrm{mg} / \mathrm{g}$ Lipozyme, molar ratio $i$-amyl alcohol:acetic acid 2:1 and a temperature of $50^{\circ} \mathrm{C}$. The most important parameter studied at this stage is the ultrasonic power, which correlated with reaction temperature was found to be 8.5 $\mathrm{mW} / \mathrm{cm}^{3}$. Ithas been observed that an increase in ultrasonic power at low temperatures leads to an increase in ester concentration in the final reaction mass. At higher temperatures $\left(>60^{\circ} \mathrm{C}\right)$, the increase in ultrasonic power deactivates the enzyme and the ester concentration obtained decreases.

Acknowledgments: The authors acknowledge the financial support received from the Competitiveness Operational Programme 20142020, Action 1.1.4: Attracting high-level personnel from abroad in order to enhance the RD capacity, ID project: P_37_471, MY SMIS 105145, „Ultrasonic/Microwave Nonconventional Techniques as new tools for nonchemical and chemical processes", financed by contract: 47/05.09.2016

\section{References}

1. GUVENC A., KAPUCU N., BAYRAKTAR E., MEHMETOGLU U., Chem Eng Commun 190 (5-8), 2003, p. 948.

2. KHAN N.R., RATHOD V.K., Proc. Biochem., 50, 2015, p.1793.

3. WELSH F.W., WILLIAMS R.E., DAWSON K.H., J. Food Sci, 55, 1990, p. 1679.

4. FISCHER E., SPEIER A., Chemische Berichte. 28, 1895, p. 3252.

5. YADAV G.D., TRIVEDI A.H., Enzyme Microb. Technol. 32, 2003, p. 783.

6. RODRIGUES R.C., LAFUENTE R.F., J. Molec. Catal. B: Enzymatic 64, 2010, p.1.

7. VINTILA, T., GHERMAN, V.D., POPA, N., POPESCU D., BUZATU C., MOTOC M. Rev. Chim. (Bucharest), 68, no. 2, 2017, p. 373.

8. GAVRILAS, S., STANESCU, M.D., Rev. Chim. (Bucharest), 67, 2016, p. 219

9. SARBU, I., VASSU, T., RUSU, E., MOLDOVAN, H., CHIFIRIUC, M.C., PELINESCU, D., et al. Rev. Chim. (Bucharest), 68, no. 12, 2017, p. 3015.

10. FEHER E., ILLEOVÁ V., KELEMEN-HORVATH I., BELAFI-BAKO K., POLAKOVIC M., GUBICZA L., J. Mol. Catal. B: Enzym. 50, 2008, p. 28. 11. HARI KRISHNA S., KARANTA N.G., Biochem Biophys Acta, 1547, 2001, p. 262.

12. MILASINOVIC N., KNEZEVIC-JUGOVI Z., J AKOVLJ EVIC Z., FILIPOVIC J., KRUSIC MK, Chem. Eng. J. 181-182, 2012, p. 614.

13. MASON T.J ., Advances in Sonochemistry, 1999, Elsevier Science. 14. FITZGERALD M.E., GRIFFING V., SULLIVAN J., J. Chem. Phys. 25, 1956, p. 926.

15. NEWMAN A.P., LORIMER J.P., MASON T.J., HUNT K.R., Ultrason. Sonochem. 4(2), 1997, p. 153.

16. PLESSET M.S., CHAPMAN R.B., J. Fluid Mech. 47, 1971, p.283.

17. ARUS, V..A.., NISTOR, I.D., PLATON, N., ROSU, A.M., MUNTIANU, G., JINESCU, C., Rev. Chim. (Bucharest), 66, no. 1, 2015, p. 88.

18. IORDACHE M., POPESCU L.R., PASCU L.F., IORDACHE I., MARINOIU

A. Rev.Chim. (Bucharest), 68, no. 5, 2017. p. 1019.

19. DELGADO-POVEDANO M.M., LUQUE DE CASTRO M.D., Analytica Chimica Acta 889, 2015, p. 1.

20. KWIATKOWSKA B., BENNETT J., AKUNNA J., WALKER G.M., BREMNER D.H., Biotechnol. Adv., 29(6), 2011, p. 768.

21. SANCHETI S.V. GOGATE P.R., Ultrason. Sonochem. 36, 2017, p. 527.

22. BANSODE S.R., RATHOD V.K., Process Biochemistry, 49, 2014, p.1297.

23. KIKUCHI T., UCHIDA T., J. Phys.: Conf. Ser. 279, 2011, p. 1.

24. UEDA S., WATANABE A., TSUJ I F., J. Electrochem. Soc. Jpn., 19, 1951, p. 142.

25. UEDA S., WATANABE A., TSUJ I F., J. Electrochem. Soc. Jpn., 19, 1951, p. 193.

Manuscript received: 1.02 .2018 